the place of the Christian family in a Christian community.

M J BRUETON Consultant Paediatrician and Senior Lecturer in Child Health, Department of Child Health, Westminster Children's Hospital, Vincent Square, London SWIP 2NS

\section{Health: The Foundations for Achievement}

David Seedhouse, 104 pages, Chichester, £5.95, John Wiley \& Sons, 1986

Most ethical problems in medicine arise as a result of new developments designed to reduce morbidity and mortality and increase health. But what exactly is meant by the term 'health'? The author of this text is a professional philosopher who addresses this question in depth. A dictionary definition is certainly not sufficient. Nor is the often quoted definition of health, as being the absence of disease, helpful, since it merely emphasises only one aspect of the problem - namely the medical. Confusion arises because the term is ambiguous and may have different meanings for different people - the so-called 'Idols of the Market Place' of Francis Bacon.

The difficulties are exemplified in seven brief case histories; a young man who suffers from delusions which affect his work, a middle-aged married man whose only leisure activity is watching $\mathrm{TV}$, a young woman who is now paraplegic following a car accident, a mother with cancer of the breast, an unemployed couple, a West-Indian youth on probation, and a successful businessman who drinks and smokes too much. The health status of each of these individuals is considered from the point of view of a doctor, a social scientist, an 'idealist', and a humanist. It soon becomes clear that each has different ideas as to who is healthy and who is not.

The author then proceeds to discuss various theories of health, including the idea of 'human potential', and concludes that '... all theories of health and all approaches designed to increase health are intended to advise against, to prevent the creation of, or to remove, obstacles to the achievement of human potential (my italics). These obstacles may be biological, environmental, societal, familial or personal'.
However, the author is quick to emphasise that the individual's potential should be realistic given his age and situation. Thus health is considered as 'the foundations for achievement' in biological, physical, emotional, intellectual, spiritual, creative and recreational terms. Viewed in this broader context then none of the seven cases might be considered really healthy.

Finally, the author argues that this concept of health broadens the scope of health education from merely emphasising disease prevention to actually creating health through getting individuals to recognise their potentials for achievement. An interesting and provocative book which is well worth reading.

ALAN EMERY

Emeritus Professor of Human Genetics and University Fellow, Edinburgh

\section{Bioethics and Belief: Religion and Medicine in Dialogue}

John Mahoney, 127 pages, London, $£ 3.95$, Sheed and Ward, 1986

This is a reprint of a book first published in 1984. Then it had the Imprimatur of the Archdiocese of Westminster. Subsequently there were protests in some Roman Catholic circles that the book was not in conformity on certain aspects of medical ethics with that Church's teaching, and that some conclusions advanced in it were at variance with that teaching and therefore erroneous.

This is particularly the case with respect to the moral status to be recognised in the early embryo of the human species. In June 1986 the Imprimatur was withdrawn and the book now appears without it. Later in that year Mahoney, one of the most distinguished moral theologians in Britain, succeeded to the Chair of Moral and Social Theology in King's College, London. In the first instance therefore, this book must be of great interest to Roman Catholics. But it has a much wider relevance. Mahoney's clear and concise moral reasoning on some of the most important current issues in medical ethics basically depends on the recognition of an element of mystery in life, especially human life, which leads to a certain reverence in thought and action in relation to it. He himself relates it to Christian belief, but it can be widely shared by those of other faiths and philosophies, and one hopes it would be a brash person who did not share it. Mahoney works out its implications almost entirely in relation to recent Roman Catholic documents, but it is easy to place them in a wider context. The sting for the Roman Catholic Church, which is liable to overcall the authority and fixity of what is not strictly claimed to be infallible teaching, comes when Mahoney shows that in some cases different conclusions are possible from the same premises, and that in some others there are inconsistencies behind the reasoning of official documents. $\mathrm{He}$ is the more persuasive because he handles the documents with scrupulous care and respect. Presumably that is why the book was at first given the Imprimatur.

In questions of human fertility and control he shows that procreation is a complex phenomenon and not merely a biological one, and that this allows for the legitimacy in certain circumstances of new human powers of control of fertility. He considers issues in death and dying, and in medical research and experiments on human subjects. Tho chapter on the beginning of life includes the most detailed of the author' discussions on the nature of the humant person, and it is the one place where he does seem to get entangled in a legacy of Aristotelian-Roman Catholic teaching. This teaching concerns the concept of the soul as a simple, spiritual substance created by God in an act of direct and immediate creation. Mahoney at first seems to go along with this to a surprising extent, but he concludes that 'the traditional Christian philosophical and theological doctrine of the human soul is in a thoroughly unsatisfactory state, particularly in the light of embryological studies' (p100). These are wise words, but the thought is not new. It is a pity that the Vatican authorities do not take them to heart.

RONALD PRESTON Emeritus Professor of Socia and Pastoral Theology, University of Manchester

\section{In Search of the Modern Hippocrates}

Roger J Bulger, editor, 256 pages, Iowa, $\$ 27.50$, University of Iowa Press, 1987

According to the editor, this collection of 17 essays was compiled in the belief that the Hippocratic oath needed 